\title{
ANALISIS PEMASARAN RUMPUT LAUT DI WILAYAH POTENSIAL DI INDONESIA
}

\author{
Oleh : \\ Yayan Hikmayani, Tenny Aprilliani dan Achmad Zamroni*
}

\begin{abstract}
ABSTRAK
Riset tentang pemasaran rumput laut telah dilakukan pada tahun 2005. Tujuannya adalah mengetahui struktur pasar dan efisiensi pemasaran rumput laut di beberapa wilayah potensial di Indonesia. Metode yang digunakan dalam penelitian ini adalah metode survei. Data yang digunakan adalah data primer dan data sekunder. Data primer yang terdiri dari data harga jual dan beli rumput laut, lembaga pemasaran, biaya pemasaran, biaya produksi, lokasi pasar yang diperoleh dari hasil wawancara dengan responden. Data sekunder diperoleh dari data statistik perikanan, laporan tahunan Dinas Perikanan, data ekspor impor yang diperoleh dari instansi-instansi terkait. Pemilihan responden dilakukan secara purposive sampling, sehingga diperoleh dari tingkat pembudidaya, pedagang pengumpul, pedagang besar dan eksportir atau pabrik pengolahan rumput laut. Analisis data yang dilakukan adalah analisis saluran pemasaran, marjin pemasaran, struktur pasar serta efisiensi pemasaran rumput laut. Hasil analisis menunjukkan bahwa lembaga pemasaran yang terlibat dalam pemasaran rumput laut terdiri dari pedagang pengumpul baik di tingkat desa maupun kecamatan, pedagang besar yang berlokasi di kota kabupaten serta eksportir atau pabrik pengolahan yang berada di ibukota propinsi. Hasil analisis marjin pemasaran diketahui bahwa marjin terbesar pemasaran rumput laut di tingkat pedagang pengumpul yang terdapat di Kabupaten Sumenep yaitu mencapai Rp. 880/kg, selanjutnya Sumbawa dan Jeneponto. Marjin pemasaran di tingkat pedagang besar terdapat di Bima dan Sumenep. Hasil analisis struktur pasar menunjukkan bahwa struktur pasar rumput laut yang terbentuk adalah oligopoli baik yang terjadi di tingkat pedagang pengumpul, pedagang besar maupun eksportir. Hasil analisis efisiensi pasar rumput laut menunjukkan bahwa pasar rumput laut yang paling efisien terdapat di Karimun Jawa, kemudian diikuti oleh wilayah lain seperti Sumbawa, Badung, Jeneponto, Bima dan Sumenep.
\end{abstract}

\section{Kata kunci : Struktur Pasar, Efisiensi Pemasaran, Rumput Laut}

\section{Abstract : Seaweed Marketing Analysis in Potential Regencies of in Indonesia. By Yayan Hikmayani, Tenny Apriliani and Achmad Zamroni}

Research on seaweeds marketing has been done in 2005. The aim of the research was to study the market structure and seaweeds marketing efficiency at some potential regions in Indonesia. Method used in this research was a survey method. Respondents were fish farmers, traders, wholesalers, middlemen, and processing industries or exporters. Respondent was taken purposived. Analysis were done by using market chain analysis, marketing margin, market structure and seaweeds marketing efficiency. Results showed that marketing institutions consist of middleman at village and sub district level, wholesaler at district and exporter or processing industry at province level. Based on marketing margin analysis showed that the middleman at Sumenep province has the maximum margin of seaweed marketing which is Rp 880 per $\mathrm{kg}$, followed by Sumbawa and Jeneponto District. The highest marketing margin at the wholesaler level detected in Bima and Sumenep. The result of marketing structure analysis showed that seaweed marketing structure was oligopoly at the middleman level, wholesaler, and exporter/ processing industry. The result from marketing efficiency analysis of seaweed shows that tho most efficient seaweed market was Karimun Jawa, followed by Sumbawa, Badung, Jeneponto, Bima and Sumenep.

Key Word : Market Structure, Marketing Efficiency, Seaweed.

Peneliti Pada Balai Besar Riset Sosial Ekonomi Kelautan dan Perikanan, BRKP-DKP.

JI. KS TUBUN Petamburan VI Slipi Jakarta 10260. Telp. (021) 53650162 


\section{PENDAHULUAN}

Pemerintah menempatkan rumput laut sebagai salah satu komoditas yang diunggulkan dalam program revitalisasi sektor kelautan dan perikanan. Hal ini menunjukkan bahwa rumput laut sebagai komoditas andalan akan mampu meningkatkan ekonomi khususnya sektor kelautan dan perikanan. Tujuan pemerintah tersebut sangat beralasan, mengingat sumberdaya yang tersedia sangat mendukung keberhasilan revitalisasi. Sumberdaya alam rumput laut di Indonesia tercatat sedikitnya sekitar 555 jenis, 55 jenis diketahui mempunyai nilai ekonomis tinggi, diantaranya Eucheuma sp, Gracillaria dan Gelidium. Disamping itu potensi lahan yang bisa dimanfaatkan untuk budidaya rumput laut cukup besar, mencapai 2,1 juta ha. (Dahuri, 2004).

Kebutuhan pasar terhadap rumput laut terus meningkat setiap tahun. Kebutuhan dunia terhadap rumput laut semakin lama semakin meningkat. Kebutuhan total rumput laut saat ini diperkirakan sekitar 40.000 ton per tahun yang terdiri dari kebutuhan dalam negeri 22.000 ton pertahun dan untuk ekspor sekitar 18.000 ton per tahun, tetapi kenyataannya kebutuhan tersebut baru terpenuhi sekitar 30.000 ton per tahun. Potensi lahan budidaya untuk Euchema $s p$ yang dapat diusahakan oleh pembudidaya rumput laut saat ini lebih dari 10.000 ha dengan produksi lebih dari 400.000 ton, nilai ini belum termasuk potensi tambak yang dapat diusahakan untuk budidaya Gracillaria. (Dahuri, 2004).

Permasalahan pada pengembangan rumput laut akhir-akhir ini adalah berkaitan dengan aspek pemasaran. Pembudidaya rumput laut belum merasakan banyak keuntungan dari kegiatan pemasaran rumput laut terutama dalam bentuk kering. Masalah pemasaran tersebut diduga terkait dengan aspek kelembagaan, jaringan pemasaran, dan gap/kesenjangan komunikasi antara produsen dan penggunanya. Panjangnya rantai pemasaran rumput laut menyebabkan margin yang diterima pembudidaya relatif masih kecil sedangkan produk yang dijual masih sangat terbatas pada bahan mentah (raw material) sehingga pembudidaya belum mendapatkan nilai tambah (value added) dari hasil budidayanya tersebut. Produksi yang dihasilkan oleh pembudidaya rumput laut sering kali tidak sesuai dengan standard yang ditetapkan oleh industri pengolahan atau eksportir sehingga hal ini menjadi alasan bagi industri untuk membeli rumput laut dengan harga murah. Permasalahan-permasalahan tersebut secara umum telah mengindikasikan bahwa informasi produk dan informasi pasar belum banyak diketahui oleh stakeholder terutama pembudidaya rumput laut.

$$
\text { Menurut Nikijuluw (2005), }
$$
permasalahan pemasaran tersebut berkembang lebih serius dengan adanya peningkatan perdagangan rumput laut mentah dari Indonesia ke luar negeri terutama ke Filipina. Gejala ini sedikit banyak kontradiktif dengan gejala yang terjadi pada pemasokan bahan baku ke pengolah dalam negeri yang ternyata banyak mengeluh kesulitan dalam memperoleh bahan baku rumput laut basah maupun kering. Oleh karena itu, makalah ini akan memberikan gambaran tentang struktur pasar rumput laut serta efisiensi pemasarannya ditinjau dari sisi produsen dan konsumen. Informasi struktur pasar, melihat diantaranya jumlah lembaga pemasaran yang ada, hambatan bagi pesaing baru untuk memasuki pasar dan lain-lain. Efisiensi pemasaran melihat tingkat efisiensi operasional yang diukur dari biaya pemasaran dan marjin pemasaran.

\section{METODE}

\section{Waktu dan Lokasi Penelitian}

Riset pemasaran rumput laut dilakukan pada tahun 2005 yang difasilitasi oleh Balai Besar Riset Sosial Ekonomi Kelautan dan Perikanan dengan menggunakan dana APBN 
(Anggaran Pendapatan dan Belanja Negara) Tahun 2005. Lokasi yang menjadi obyek penelitian ini diantaranya yaitu wilayah Kabupaten Jepara (Karimun Jawa) yang mewakili Propinsi Jawa Tengah; Kabupaten Sumenep mewakili Propinsi Jawa Timur; Kabupaten Badung mewakili Propinsi Bali, Kabupaten Sumbawa mewakili Propinsi Nusa Tenggara Barat; Kabupaten Jeneponto mewakili Propinsi Sulawesi Selatan yang merupakan wilayah-wilayah potensial untuk budidaya rumput laut.

\section{Data dan Sumber Data}

Data yang digunakan dalam penelitian ini terdiri dari data primer dan sekunder. Data primer terdiri dari data; harga rumput laut, biaya pemasaran, jumlah pedagang, jalur pemasaran, lokasi pasar. Data primer diperoleh dari responden yang dipilih secara purposive yaitu pembudidaya rumput laut, pedagang pengumpul, pedagang besar, eksportir/industri pengolahan. Data sekunder digunakan untuk memperoleh informasi yang berkaitan dengan pemasaran yang diperoleh dari instansi-instansi terkait diantaranya Dinas Perikanan dan Kelautan, Dinas Perdagangan dan Perindustrian serta instansi terkait lain di lokasi penelitian.

\section{Metode Pengumpulan Data}

Metode pengumpulan data yang digunakan dalam penelitian ini yaitu metode survey. Pengambilan data primer dilakukan melalui wawancara dengan responden secara mendalam (indepth interview) dengan menggunakan kuesioner yang telah disediakan. Pemilihan responden dilakukan secara purposive untuk menentukan pembudidaya rumput laut, pedagang pengumpul di desa, pedagang pengumpul di kecamatan, pedagang besar serta eksportir yang terlibat dalam kegiatan pemasaran rumput laut di lokasi penelitian.
Jumlah responden pembudidaya diperoleh 5 orang pada masing-masing lokasi dari kelompok tani berbeda, responden pedagang pengumpul diperoleh 2 orang dan responden pedagang besar ditetapkan pedagang yang menampung rumput laut dari lokasi penelitian, sedangkan responden eksportir atau industri pengolahan terdiri dari 5 perusahaan pengolah yaitu PT Gumindo Perkasa Industri, PT Agarindo Bogatama, PT Amarta Sari Lestari, PT Phoenix Mas, CV Agar Sari Jaya.

\section{Analisis Data}

Data primer dan sekunder yang telah terkumpul kemudian diolah dan dianalisis. Analisis-analisis yang dilakukan diantaranya saluran pemasaran, marjin pemasaran, struktur pasar dan analisis efisiensi pemasaran. Pertama, analisis saluran pemasaran dilakukan secara deskriptif dengan mengamati lembaga pemasaran yang terlibat dalam penyampaian rumput laut dimulai dari pembudidaya sampai ke konsumen akhir. Kedua, analisis marjin pemasaran dilakukan terhadap setiap lembaga pemasaran yang terlibat. Marjin pemasaran dihitung berdasarkan pengurangan harga penjualan dengan harga pembelian pada setiap lembaga pemasaran. Besarnya marjin pemasaran merupakan penjumlahan dari biaya-biaya pemasaran dan keuntungan yang diperoleh lembaga pemasaran. Secara matematis marjin pemasaran dirumuskan sebagai berikut:

$\mathrm{Mi}=$ Psi $-\mathrm{Pbi}$

$\mathrm{Mi}=\mathrm{Ci}-\pi \mathrm{i}$

Dimana :

$\mathrm{Mi}=$ marjin pemasaran pasar tingkat ke- $\mathrm{i}$

Psi = harga jual pasar tingkat ke-i

$\mathrm{Pbi}=$ harga beli pasar tingkat ke-i

$\mathrm{Ci}=$ Biaya pemasaran pada tingkat ke-i

$\pi \mathrm{i}=$ keuntungan lembaga pemasaran pada pasar tingkat ke-i 
Ketiga, analisis struktur pasar dilakukan secara deskriptif, mengacu kepada Kuncoro (2002) dengan memperhatikan beberapa hal diantaranya; (1) jumlah lembaga pemasaran yang ada, (2) hambatan bagi pesaing baru untuk memasuki pasar, (3) keadaan produk yang diperjualbelikan, (4) penentu harga, (5) sumber informasi. Kohl dan Uhl (1990) membedakan struktur pasar 4 (empat) tipe dengan masing-masing mempunyai ciri-ciri yangberbeda. Empat (4) tipe struktur pasar tersebut diantaranya struktur pasar; 1) bersaing sempurna, 2) kompetisi monopolistik, 3) oligopoli dan 4) monopoli. Beberapa hal yang mencirikan masing-masing tipe struktur pasar dapat dilihat pada Tabel 1.

Tabel 1. Perbandingan Secara Umum Bentuk-Bentuk Struktur Pasar

Table 1. General Comparation of Market Struktur Form

\begin{tabular}{|c|c|c|c|c|}
\hline $\begin{array}{c}\text { Uraian / } \\
\text { Description }\end{array}$ & $\begin{array}{c}\text { Bersaing } \\
\text { Sempurna / } \\
\text { Perfect } \\
\text { Competition }\end{array}$ & $\begin{array}{c}\text { Kompetisi } \\
\text { Monopolistik / } \\
\text { Monopolistic } \\
\text { Competition }\end{array}$ & $\begin{array}{l}\text { Oligopoli / } \\
\text { Oligopoly }\end{array}$ & $\begin{array}{l}\text { Monopoli / } \\
\text { Monopoly }\end{array}$ \\
\hline $\begin{array}{l}\text { Jumlah Penjual/ } \\
\text { Amount of Seller }\end{array}$ & $\begin{array}{l}\text { Sangat banyak / } \\
\text { Plenty }\end{array}$ & $\begin{array}{l}\text { Banyak / } \\
\text { A lot of }\end{array}$ & $\begin{array}{l}\text { Sedikit I } \\
\text { A little }\end{array}$ & $\begin{array}{l}\text { Satu / } \\
\text { one }\end{array}$ \\
\hline $\begin{array}{l}\text { Kesamaan } \\
\text { Produk / } \\
\text { Product equality }\end{array}$ & $\begin{array}{l}\text { Homogenus } \\
\text { identik / } \\
\text { Homogenous } \\
\text { Identic }\end{array}$ & $\begin{array}{l}\text { Berbeda, } \\
\text { beberapa variasi / } \\
\text { Different, some } \\
\text { variation }\end{array}$ & $\begin{array}{l}\text { Sama atau berbeda / } \\
\text { Same or different }\end{array}$ & $\begin{array}{l}\text { Unik, tidak } \\
\text { memiliki produk } \\
\text { substitusi / } \\
\text { Unique, no } \\
\text { substitution } \\
\text { product }\end{array}$ \\
\hline $\begin{array}{l}\text { Kemudahan } \\
\text { Perusahaan Baru } \\
\text { Masuk / } \\
\text { Amenity of } \\
\text { entering new } \\
\text { company }\end{array}$ & $\begin{array}{l}\text { Mudah tidak } \\
\text { ada rintangan / } \\
\text { Easy no } \\
\text { Barriers }\end{array}$ & $\begin{array}{l}\text { Relatif mudah / } \\
\text { Relatively Easy }\end{array}$ & $\begin{array}{l}\text { Sulit, ada rintangan } \\
\text { significan / } \\
\text { Difficult, there are } \\
\text { Significant Barriers }\end{array}$ & $\begin{array}{l}\text { Dibatasi / } \\
\text { limited }\end{array}$ \\
\hline $\begin{array}{l}\text { Kemampuan } \\
\text { Mempengaruhi } \\
\text { Harga / } \\
\text { ability of } \\
\text { influencing } \\
\text { market }\end{array}$ & $\begin{array}{l}\text { Tidak dapat / } \\
\text { cannot }\end{array}$ & $\begin{array}{l}\text { Sedikit, tetapi } \\
\text { dibatasi oleh } \\
\text { adanya barang } \\
\text { substitusi / } \\
\text { A little, but } \\
\text { Limited by } \\
\text { Substitution }\end{array}$ & $\begin{array}{l}\text { Mampu, tapi tetap } \\
\text { memperhitungkan } \\
\text { prilaku pesaing / } \\
\text { Able, but still reckoning } \\
\text { competitor behavior }\end{array}$ & $\begin{array}{l}\text { Mampu, kecuali } \\
\text { ada regulasi / } \\
\text { Able, except } \\
\text { there is } \\
\text { regulation }\end{array}$ \\
\hline $\begin{array}{l}\text { Contoh / } \\
\text { example }\end{array}$ & $\begin{array}{l}\text { Peran } \\
\text { pembudidaya / } \\
\text { Role of fish } \\
\text { farmer }\end{array}$ & $\begin{array}{l}\text { goods } \\
\text { Toko makanan } \\
\text { kecil, restoran, } \\
\text { toko milik } \\
\text { pembudidaya / } \\
\text { Snack shop, } \\
\text { restaurant, shop } \\
\text { owned by fish } \\
\text { farmer }\end{array}$ & $\begin{array}{l}\text { Jaringan toko, } \\
\text { pengolahan makanan, } \\
\text { pedagang grosir / } \\
\text { Shop network, food } \\
\text { processing, grocery } \\
\text { merchant }\end{array}$ & $\begin{array}{l}\text { BUMN / } \\
\text { Government } \\
\text { Owned } \\
\text { company }\end{array}$ \\
\hline
\end{tabular}


Keempat, analisis efisiensi pemasaran dilakukan secara deskriptif dengan mengacu pada Kohl dan Uhl (1990) yang membagi efisiensi pemasaran kedalam dua bagian yaitu: 1) efisiensi operasional adalah perubahan dalam biaya pemasaran sebagai akibat perubahan biaya penyelenggaraan fungsi-fungsi pemasaran (pembelian, penjualan, penyimpanan, pengangkutan, pengolahan, pembiayaan, standarisasi, tanggungan resiko, informasi pasar, dan harga) tanpa mempengaruhi sisi output. Efisiensi pemasaran diukur dari margin pemasaran dan biaya pemasaran. 2) efisiensi harga menekankan pada kemampuan pasar dalam melakukan efisiensi alokasi sumber daya dan memaksimumkan output. Efisiensi harga diukur melalui korelasi harga yang terjadi untuk komoditas yang sama pada berbagai tingkat pasar.

\section{HASIL DAN PEMBAHASAN}

\section{Gambaran umum lokasi penelitian}

\section{Sulawesi Selatan}

Kabupaten Jeneponto merupakan lokasi yang merupakan pencerminan pengembangan budidaya rumput laut di Sulawesi Selatan. Luas wilayah Kabupaten Jeneponto sekitar $749,79 \mathrm{~km}^{2}$ dengan panjang garis pantai $114 \mathrm{~km}$ yang terdiri dari 10 kecamatan dan 112 desa dan kelurahan (tambah satu desa persiapan).
Pada tahun 2004, produksi perikanan sebesar 54.764 ton yang terdiri dari penangkapan ikan laut sebesar $13.318,8$ ton (naik 1,5\%) dan budidaya rumput laut sebesar $9.310,5$ ton (naik 139,5 \%) sedangkan perikanan darat yaitu budidaya tambak jumlah produksi pada tahun 2004 sebesar 1.897,3 ton (naik 6,4\%), budidaya air tawar sebesar 119, 2 ton (naik 12,6) dan produksi garam rakyat tahun 2004 sebesar 30.118,2 ton (naik 9,4\%).

Pada tahun 2004 terdapat 3 Kecamatan dengan produksi yang cukup tinggi (diatas 3.500 ton) yaitu Kecamatan Tamalatea $7.777,26$ ton, Batang 3.7756,02 ton dan Kecamatan Bangkala 3.676,45 ton. Jumlah produksi 15 209,73 ton atau sekitar (67,21\%) dari total keseluruhan. Sedangkan Kecamatan lainnya mempunyai produksi dibawah 3.500 ton dengan penyebaran yang tidak merata. Produksi perikanan darat pada tahun 2004 yang terbanyak terdapat di Kecamatan Bangkala (623,9 ton), Tamalatea (459,4 ton) dan Arungkeke (368,2 ton); sedangkan prodyksi di Kecamatan lainnya produksi dibawah 300 ton. Produksi perikanan darat yang berasal dari budidaya ikan umumnya berasal dari tambak air payau yaitu Kecamatan Bangkala (780,5 ton), Tamalatea (456,2 ton) dan Arungkeke (313,4 ton), sedangkan produksi terendah terdapat di Kecamatan Binamu 135,2 ton. Penyebaran produksi perikanan di setiap kecamatan di Kabupaten Jeneponto dapat dilihat pada Tabel 2.

\section{Tabel 2. Perkembangan Jumlah Produksi Rumput Laut di Kabupaten Jeneponto, Tahun 2000 - 2004 (ton)}

Table 2. Seaweed Production Growth in Jeneponto District, Year 2000-2004 (ton)

\begin{tabular}{lrrrrr}
\hline Kecamatan & \multicolumn{5}{c}{ Tahun } \\
\cline { 2 - 5 } & $\mathbf{2 0 0 0}$ & $\mathbf{2 0 0 1}$ & $\mathbf{2 0 0 2}$ & $\mathbf{2 0 0 3}$ & \multicolumn{1}{c}{$\mathbf{2 0 0 4}$} \\
\hline Bangkala Barat & - & 630,5 & 631,1 & $\mathbf{4 8 5 , 5}$ & 432 \\
Bangkala & $1.677,2$ & 936,6 & $1.036,9$ & 1.084 & $1.745,25$ \\
Tamalatea & $1.467,2$ & 1.118 & $1.118,1$ & 1.202 & $4.700,66$ \\
Binamu & 282,1 & 396,5 & 398,4 & 269,6 & 962,68 \\
Batang & 161,5 & 357,5 & 367,8 & 339,9 & 1003,59 \\
Arungkeke & - & 240,5 & 246,9 & 504,3 & 466,32 \\
\hline
\end{tabular}

Sumber: Dinas Perikanan dan Kelautan Kabupaten Jeneponto, 2004

Source : Marine and Fisheries Service in District of Jeneponto, 2004 


\section{Jawa Timur}

Kabupaten Sumenep merupakan lokasi yang dapat mewakili Propinsi Jawa Timur untuk budidaya rumput laut. Budidaya rumput laut di Kabupaten Sumenep telah dimulai sejak tahun 1987, namun tidak berkembang disebabkan kendala dalam pemasarannya. Usaha budidaya rumput laut baru dimulai lagi sejak tahun 1991 yang dipelopori oleh pengusaha yang memberikan modal ke petani serta bimbingan teknis dari BPPT. Sampai saat ini budidaya rumput laut sudah diusahakan di 7 kecamatan dari 27 kecamatan yang ada. Kegiatan budidaya rumput laut telah menjadi mata pencaharian sampingan disamping sebagi nelayan. Teknologi budidaya yang digunakan menggunakan rakit bambu dengan ukuran beragam dimulai dari ukuran $8 \times 9 \mathrm{~m}^{2}$ sampai $10 \times 12 \mathrm{~m}^{2}$. Produksi per petak rata-rata mencapai $400 \mathrm{~kg}$ basah atau setara $200 \mathrm{~kg}$ kering. Disamping teknologi rakit, budidaya dilakukan dengan sistem longline. Jumlah petani pada tahun 2004 tercatat sebanyak 4722 orang dengan luas areal 144,97 Ha. Dari luas areal yang diuasahakan produksi rumput laut kering yang dihasilkan sebanyak 38.847.117 ton dengan nilai jual sebesar Rp. 135.964.909.500. Kadar air rumput laut dari petani berkisar 38 - 40\%, sedangkan dari pedagang besar sekitar 34 -36 persen.

\section{Bali}

Kabupaten Badung dapat mencerminkan keterwakilan pengembangan rumput laut di Propinsi Bali. Pemanfaatan potensi laut sebagai lahan budidaya di Kabupaten Badung baru terbatas pada usaha pengembangan budidaya rumput laut. Pengembangan budidaya rumput laut terdapat di Pantai Nusa Dua, Sawangan, Petangan, Geger, Kutuh, Padang-padang, Labuan Sait, dan Ungasan. Jenis rumput laut yang dibudidayakan meliputi jenis Eucheuma cotonii dan Eucheuma spinosum. Sistem budidaya rumput laut yang digunakan adalah sistem budidaya apung (sistem rakit) dan sistem lepas dasar.

Luas areal yang berpotensi untuk pengembangan rumput laut (sekitar 125 ha), yang dimanfaatkan hanya sekitar 98 ha, atau hanya 78 persen yang baru dimanfaatkan untuk pengembangan budidaya rumput laut. Pada tahun 2004 luas areal pengembangan rumput laut yang sudah diusahakan mencapai 98 ha dengan jumlah petani rumput laut sebanyak 674 orang. Produksi rumput laut yang dicapai tahun 2004 sebanyak 4.585,6 ton. Jika dibandingkan dengan produksi rumput laut tahun 2003 yang mencapai $4.414,8$ ton maka terjadi kenaikan sebesar 3,8 persen. Masyarakat mulai tertarik untuk berinvestasi di usaha budidaya rumput laut. Investasi swasta atau masyarakat pada tahun 2003 hanya mencapai Rp 28.142.670.125 dan tahun 2004 naik menjadi Rp 415.901.555 atau mengalami peningkatan 1,5 persen dari tahun sebelumnya. Peningkatan investasi ini terutama terjadi di bidang perikanan pada usaha pengolahan dan budidaya rumput laut. Pada tahun 2004 jumlah komoditas perikanan yang diperdagangkan antar pulau terdiri dari komoditas rumput laut sebesar 4.586,6 ton dengan nilai $\mathrm{Rp} 22.010 .400 .000$. Budidaya rumput laut merupakan penghasilan utama masyarakat pesisir, setelah penangkapan ikan. Hal ini bisa dilihat dari kontribusi rumput laut ke pendapatan masyarakat per tahun, yaitu sebesar Rp 28.821.334, sedangkan kontribusi penangkapan ikan tradisional terhadap pendapatan masyarakat per tahun sebesar Rp 38.401.354.

\section{Jawa Tengah}

Kecamatan Karimunjawa merupakan lokasi yang mencerminkan keterwakilan pengembangan budidaya rumput laut di Jawa Tengah. Kecamatan Karimunjawa merupakan salah satu daerah di Kabupaten Jepara yang terletak 45 mil laut di sebelah utara Kabupaten Jepara yang secara geografi terletak pada $5^{\circ} 40^{\prime} 39^{\prime \prime}-5^{\circ} 55^{\prime} 00^{\prime \prime}$ LS, $10^{\circ} 05^{\prime} 57^{\prime \prime}-11^{\circ} 31^{\prime} 15^{\prime \prime}$ BT. 
Luas perairan $1.626,8 \mathrm{Km}^{2}(162.680 \mathrm{Ha})$ dan luas daratan $7.120 \mathrm{Ha}$ yang mempunyai gugus kepulauan sebanyak 27 (dua puluh tujuh).

Pengembangan rumput laut di Karimunjawa berada di Pulau Menjangan Besar dengan luas areal $5 \mathrm{Ha}$ dan jumlah rakit sebanyak 30 rakit yang berukuran $3 \times 4$ meter. Jumlah simpul tanaman rumput laut setiap rakitnya sebanyak 250 simpul. Luas lahan rumput laut di Batu Sawang $1 \mathrm{Ha}$ dan di Kemloko sebanyak 100 rakit. Lokasi pengembangan berikutnya adalah Pulau Menjangan Kecil, Karimunjawa (legon Boyo), Nyamplungan, Parang, Nyamuk dan Genting.

Pemanfaatan rumput laut saat ini oleh masyarakat karimunjawa masih skala tradisional terutama untuk aspek pengolahannya, diantaranya digunakan untuk manisan, rumput laut kering tawar dan peyek rumput laut yang dipasarkan untuk oleh-oleh atau cinderamata bagi para wisatawan yang berkunjung di Kepulauan Karimunjawa. Kebutuhan untuk pengolahan tersebut membutuhkan rumput laut basah mencapai 10 ton/bulan. Sedangkan untuk industri pengeringan selama ini masih kekurangan bahan baku berupa rumput laut basah. Rumput laut di Karimunjawa dipasarkan dalam bentuk basah dan dalam bentuk kering. Penjualan rumput laut basah dilakukan kepada pengepul -pengepul yang ada di sana, sedangkan rumput laut kering biasanya dijual oleh pengepul-pengepul tersebut ke industri. Industri-industri tersebut bentuk kering, maupun tepung karagenan. Pengembangan rumput laut di Karimunjawa mengalami beberapa kendala diantaranya kepastian bahan baku, budaya masyarakat, kepentingan dari berbagai pihak yang terlibat dalam pengembangan rumput laut, hama ikan smadar, penyakit, lumut, harga dasar rumput laut basah yang dirasakan petani masih rendah yaitu berkisar antara Rp. 300 - 350,serta letaknya di wilayah konservasi.

\section{Nusa Tenggara Barat}

Propinsi Nusa Tenggara Barat (NTB) mempunyai potensi sumberdaya pesisir dan laut yang cukup tinggi, yaitu luas perairan lautnya sekitar $29.159,04 \mathrm{~km}^{2}$, panjang pantai $2.333 \mathrm{~km}$ dan perairan karang sekitar 8.601 $\mathrm{km}^{2}$. Ekosistem penting lainnya adalah padang lamun (seagrass beds), rumput laut (sea weeds), pantai berpasir dan ekosistem mangrove. Luas total wilayah Propinsi NTB mencapai 49.312,19 $\mathrm{km}^{2}$ meliputi luas daratan 20. $153,15 \mathrm{~km}^{2}$ dan perairan laut $16.306,90 \mathrm{~km}^{2}$. Potensi areal budidaya laut untuk komoditas rumput laut seluas 22.270 ha. Dari 8 kabupaten yang ada di Nusa Tenggara Barat, enam diantaranya memiliki potensi rumput laut. Pulau Sumbawa merupakan kabupaten yang memiliki potensi rumput laut terbesar di Nusa Tenggara Barat, yaitu sekitar 15.500 ha, lalu diikuti Kabupaten Bima seluas 2.317 ha, disusul Kabupaten Lombok Timur seluas 2.000 ha, sedangkan tiga kabupaten lainnya adalah Dompu seluas 1.298 ha, Lombok Barat seluas 800 ha, dan Lombok Tengah seluas 355 ha. Dua kabupaten lainnya tidak memiliki potensi rumput laut, yaitu Kota Mataram dan Kota Bima.

Rincian potensi areal budidaya laut untuk komoditas rumput laut per kabupaten di Propinsi NTB dapat dilihat pada Tabel 3.

\section{Analisis Saluran Pemasaran}

Hasil analisis menunjukkan bahwa pemasaran rumput laut melibatkan beberapa lembaga pemasaran baik yang ada dilokasi maupun yang ada di luar lokasi budidaya baik di kabupaten maupun propinsi. Lembaga pemasaran yang terlibat secara umum di setiap lokasi hampir sama yaitu terdiri dari:

\section{a. Pedagang Pengumpul Lokal}

Pedagang pungumpul membeli rumput laut dari pembudidaya baik dengan kondisi basah (panen) maupun kering panen (kadar 
Tabel 3. Produksi Rumput Laut Menurut Kabupaten/Kota se-NTB tahun 1999-2003

Table 3. Seaweed Production Based on Sub Province/City in West Nusa Tenggara, Year 19992003

\begin{tabular}{|c|c|c|c|c|c|}
\hline \multirow{2}{*}{$\begin{array}{c}\text { Kabupaten/kota/ } \\
\text { Regency }\end{array}$} & \multicolumn{5}{|c|}{ Jumlah Produksi (ton) / Total Production } \\
\hline & 1999 & 2000 & 2001 & 2002 & 2003 \\
\hline $\begin{array}{l}\text { Lombok Barat / } \\
\text { West Lombok }\end{array}$ & - & - & 358,2 & 500,0 & $2.599,4$ \\
\hline $\begin{array}{l}\text { Lombok Tengah / } \\
\text { Central Lombok }\end{array}$ & $7.890,0$ & $8.955,0$ & $8.963,9$ & $13.259,0$ & $14.416,0$ \\
\hline $\begin{array}{l}\text { Lombok Timur / } \\
\text { East Lombok }\end{array}$ & 780,0 & 793,7 & $2.160,0$ & $2.140,0$ & $2.151,0$ \\
\hline Sumbawa & $11.282,4$ & $11.480,9$ & $11.350,5$ & $11.496,0$ & $10.560,0$ \\
\hline Dompu & $1.100,0$ & $1.119,3$ & $1.120,4$ & $1.267,2$ & $1.140,4$ \\
\hline Bima & - & - & - & 250,0 & 186,0 \\
\hline $\begin{array}{l}\text { Kota Mataram / } \\
\text { Mataram Regency }\end{array}$ & - & - & - & - & - \\
\hline $\begin{array}{l}\text { Kota Bima / } \\
\text { Bima Regency }\end{array}$ & - & - & - & - & 110,0 \\
\hline Total & $21.052,4$ & $22.348,9$ & $23.953,0$ & $28.912,2$ & $31.162,8$ \\
\hline
\end{tabular}

Sumber : Dinas Perikanan dan Kelautan Propinsi Nusa Tenggara Barat, 2004.

Source : Marine and Fisheries Services of Nusa Tenggara Barat Province, 2004

air $60 \%$ ). Harga beli untuk rumput laut basah dibeli dengan harga Rp 1000/kg dan kering Rp. 3000 - 4000/kg. Apabila pedagang pengumpul membeli rumput laut dari pembudidaya dalam kondisi basah, maka rumput laut tersebut akan dikeringkan selama 3-4 hari sehingga kadar air mencapai $40 \%$. Pedagang pengumpul bertempat di lokasi budidaya dan dibeberapa wilayah pedagang pengumpul merupakan anggota kelompok atau bahkan ketua kelompok tani. Jumlah pedagang pengumpul yang ada dilokasi budidaya sekitar 3 - 6 orang. Setelah rumput laut terkumpul cukup banyak maka rumput laut kemudian dijual ke pedagang pengumpul yang ada di kota kecamatan. Untuk daerah yang lokasinya di kota kecamatan, maka rumput laut dari pedagang pengumpul langsung dijual ke pedagang besar yang berlokasi di kota Kabupaten. Khusus untuk pembudidaya yang berada di Kabupaten Badung, pembudidaya rumput laut tergabung dalam kelompokkelompok dan mereka mendirikan koperasi yang fungsinya sebagai pengumpul untuk kemudian dijual ke agen perusahaan yang ada di daerah Denpasar. Disamping itu penyediaan gudang oleh agen yang cukup memadai dilokasi mengurangi beban biayabiaya tambahan. Koperasi mendapatkan keuntungan Rp. 100/kg rumput laut yang terjual, dan uang tersebut akan digunakan oleh anggotanya sebagai pinjaman modal yang dapat digulirkan terus diantara sesama anggotanya.

\section{b. Pedagang Besar}

Pedagang besar menerima kiriman rumput laut dari pedagang pengumpul yang sudah menjadi langganannya. Jumlah pedagang besar sangat terbatas paling banyak 3 orang, dan mereka mempunyai pedagang pengumpul yang mensuplai rumput laut kering. Sebagai contoh seorang pedagang besar yang ada di kabupaten Sumenep mempunyai pedagang pengumpul sebanyak 20 orang, sehingga dalam satu bulan saja dapat mengumpulkan rumput laut kering sebanyak ratusan ton. Namun demikian rumput laut kiriman dari pedagang pengumpul tersebut masih dikeringkan selama satu hari 
sampai kadar air mencapai 34 persen. Rumput laut yang mutunya tidak sesuai (kadar air $>40$ persen dan kotoran lebih dari 5\%) akan ditolak atau diturunkan harganya oleh pedagang besar. Antara pedagang pengumpul dengn pedagang besar terjadi ikatan bisnis yang kuat sehingga faktor kepercayaan sangat diperhatikan.

\section{c. Pabrik Pengolahan atau Eksportir}

Pusat pabrik pengolahan dan eksportir rumput laut di Indonesia sebagian besar terpusat di Surabaya. Data yang diperoleh sebanyak 19 buah perusahaan rumput laut berada di Surabaya. Pengiriman rumput laut oleh pedagang besar atau agen yang terdapat di daerah tergantung kedekatan lokasinya. Daerah seperti NTB dan Sulawesi Selatan pengiriman dilakukan sekali dalam sebulan atau apabila rumput laut sudah mencapai 15 sampai 20 ton untuk menghemat biaya transportasi.

Saluran pemasaran rumput laut secara umum di setiap lokasi hampir sama, yaitu seperti tertera pada gambar 1 .

\section{Analisis Marjin Pemasaran}

Analisis marjin pemasaran dimulai dari pedagang pengumpul yang berada di sentra produksi rumput laut sampai kepada eksportir atau pabrik pengolahan rumput laut. Komponen biaya pemasaran rumput laut terdiri dari biaya penyusutan ,transportasi, pengemasan, bongkar muat, sewa tempat dan retribusi. Komparasi biaya pemasaran di setiap lokasi dan setiap lembaga pemasaran dapat dilihat pada tabel 4 .

\section{a. Marjin Pemasaran Di Tingkat Pedagang Pengumpul}

Dari Tabel 5 dapat dilihat bahwa biaya pemasaran terbesar di tingkat pedagang pengumpul terbesar yaitu di Kabupaten
Sumenep yaitu mencapai Rp. 880/kg, kemudian diikuti oleh Kabupaten Sumbawa, Jeneponto. Biaya pemasaran tertinggi yang ditanggung oleh pedagang pengumpul di Sumenep disebabkan tingginya biaya penyusutan. Biaya penyusutan mencapai Rp. 600/kg, karena sebagian besar pedagang pengumpul di Sumenep membeli rumput laut basah dari pembudidaya. Biaya pemasaran paling kecil yaitu di Kabupaten Badung hanya Rp. 100/kg. Hal ini disebabkan adanya koperasi pembudidaya rumput laut yang mengambil alih fungsi pedagang pengumpul dengan menjalin hubungan baik dengan pedagang besar sehingga harga yang dibayarkan lebih mahal di banding wilayah lain, sedangkan biaya lebih murah dibanding wilayah lain. Sedangkan di Karimun Jawa rumput laut dijual langsung ke pihak pengolah/industri rumahtangga karena volume produksinya juga masih kecil.

Marjin pemasaran terbesar diperoleh pedagang pengumpul yang ada di Jakarta yaitu Rp. $2.000 / \mathrm{kg}$. Hal ini disebabkan karena rumput laut dijual langsung ke pedagang pengecer yang tersebar di pasar sekitar Jakarta sehingga harganya mencapai Rp 11.500. Selain itu marjin pemasaran terbesar kedua diterima oleh pedagang pengumpul yang berada di Sumenep yaitu Rp. 1900/kg. Hal ini disebabkan pembelian rumput laut kering dari pembudidaya lebih murah dibanding dengan didaerah lain yaitu hanya Rp. $2700 / \mathrm{kg}$ dan dijual dengan harga yang tinggi yaitu Rp. 6.000/kg.

\section{b. Marjin Pemasaran di Tingkat Pedagang Besar}

Biaya pemasaran ditingkat pedagang besar tidak jauh dari pedagang pengumpul terdiri dari biaya untuk pembersihan rumput laut, Grading yaitu memisahkan rumput laut yang mutunya baik dan buruk, biaya transportasi ke lokasi pabrik pengolah/eksportir, biaya penyusutan karena seringkali rumput laut ada yang masih harus dikeringkan karena kadar airnya belum 


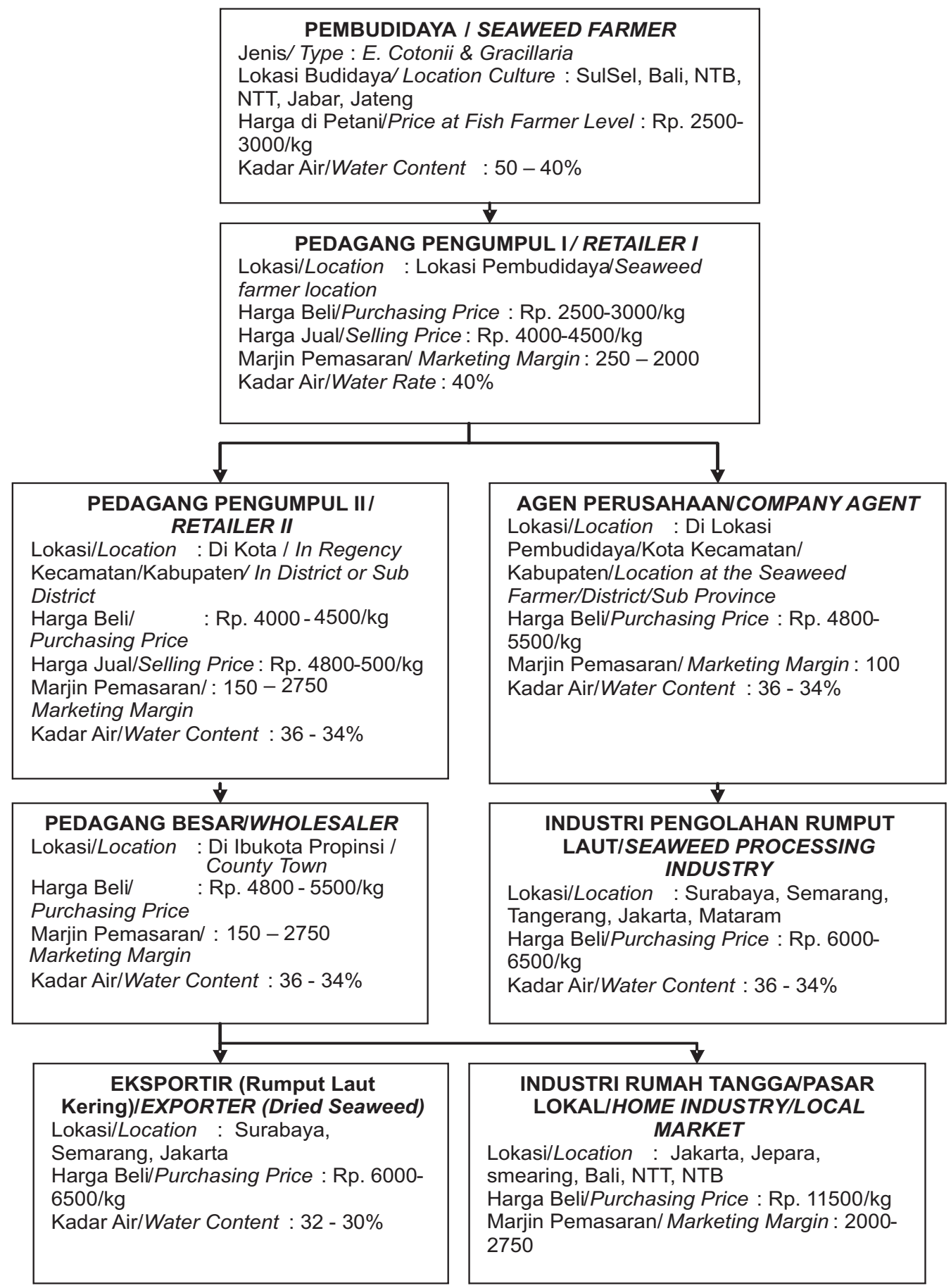

\section{Gambar 1. Saluran Pemasaran Rumput Laut}

Figure 1. Seaweed Marketing Chain 
Tabel 4. Komparasi Biaya Pemasaran Rumput Laut di beberapa Lokasi Penelitian, Tahun 2005

Table 4. Marketing Cost of Seaweed on each Study Site in 2005

\begin{tabular}{|c|c|c|c|c|c|c|}
\hline $\begin{array}{l}\text { Kabupaten/ } \\
\text { District }\end{array}$ & Karimunjawa & Sumenep & Badung & Bima & Sumbawa & Jeneponto \\
\hline $\begin{array}{l}\text { Pedagang } \\
\text { pengumpul } \\
\text { /retailer }(\mathrm{Rp} / \mathrm{kg})\end{array}$ & 0 & 880 & 100 & 140 & 500 & 450 \\
\hline $\begin{array}{l}\text { - Pembersihan / } \\
\text { sweeping }\end{array}$ & - & 40 & - & 70 & 100 & 100 \\
\hline $\begin{array}{l}\text { - Sortasi / } \\
\text { sortation }\end{array}$ & - & - & - & - & - & - \\
\hline $\begin{array}{l}\text { - Pengepakan / } \\
\text { packing }\end{array}$ & - & 10 & - & 30 & 50 & 50 \\
\hline $\begin{array}{l}\text { - Bongkar muat / } \\
\text { load/unload }\end{array}$ & - & 10 & - & - & - & - \\
\hline $\begin{array}{l}\text { - Penyusutan / } \\
\text { decrease }\end{array}$ & - & 600 & - & - & - & - \\
\hline $\begin{array}{l}\text { - Retribusi / } \\
\text { Retribution }\end{array}$ & - & & 100 & 40 & 50 & 50 \\
\hline $\begin{array}{l}\text { - Transportasi / } \\
\text { Transportation }\end{array}$ & - & 220 & - & - & 300 & 50 \\
\hline $\begin{array}{l}\text { - Sewa tempat / } \\
\text { rent a place }\end{array}$ & - & - & - & - & & 200 \\
\hline $\begin{array}{l}\text { Pedagang Besar } \\
\text { /Grosir (Rp/kg) } \\
\text { Wholesaler }\end{array}$ & 450 & 750 & 440 & 800 & 640 & 500 \\
\hline $\begin{array}{l}\text { - Pembersihan / } \\
\text { sweeping }\end{array}$ & 100 & 10 & - & 150 & 60 & 100 \\
\hline $\begin{array}{l}\text { - Sortasi / } \\
\text { sortation }\end{array}$ & - & - & - & - & 70 & 100 \\
\hline $\begin{array}{l}\text { - Pengepakan / } \\
\text { Packing }\end{array}$ & 50 & 10 & 20 & 50 & 40 & 50 \\
\hline $\begin{array}{l}\text { - Bongkar muat / } \\
\text { load/unload }\end{array}$ & - & 10 & 70 & - & 300 & - \\
\hline $\begin{array}{l}\text { - Penyusutan / } \\
\text { decrease }\end{array}$ & - & 500 & 30 & 400 & 50 & - \\
\hline $\begin{array}{l}\text { - Retribusi / } \\
\text { Retribution }\end{array}$ & 50 & - & 20 & 100 & 120 & 50 \\
\hline $\begin{array}{l}\text { - Transportasi / } \\
\text { Transportation }\end{array}$ & 250 & 220 & 200 & 100 & - & - \\
\hline $\begin{array}{l}\text { - Sewa tempat / } \\
\text { Rent a place }\end{array}$ & & & 100 & & & 200 \\
\hline
\end{tabular}

Sumber: Data Primer diolah, 2005

Source : Primary Data (Proccesed), 2005 
Tabel5. Analisis Marjin Pemasaran Rumput Laut di Tingkat Pedagang Pengumpul, Pedagang Besar/Agen Tahun 2005

Table 5. Marketing Margin of Seaweed at Retailer, Wholesaler/Agent Level in 2005

\begin{tabular}{|c|c|c|c|c|c|}
\hline $\begin{array}{c}\text { Uraian/ } \\
\text { Description }\end{array}$ & $\begin{array}{c}\text { Karimun } \\
\text { Jawa }\end{array}$ & Sumenep & Badung & Sumbawa & Jeneponto \\
\hline $\begin{array}{l}\text { - Harga Beli/ Price: } \\
\text { - Industri/Industry } \\
\text { - Eksportir/Eksporter } \\
\text { - Pengecer/Retailer } \\
\text { - Biaya Pemasaran / } \\
\text { Marketing Cost: } \\
\text { - Keuntungan/Profit } \\
\text { - Margin Pemasaran/ } \\
\text { Marketing Margin } \\
\text { - Harga Jual/Selling Price } \\
\text { - B/C Ratio }\end{array}$ & 4.000 & 6.000 & 7.000 & 6.000 & 6.000 \\
\hline $\begin{array}{l}\text { - Harga Beli Pedagang } \\
\text { Besar/Agen/Wholeseller } \\
\text { Price/Agent }\end{array}$ & 3.000 & 4.600 & 5.200 & 5.000 & 4.500 \\
\hline $\begin{array}{l}\text { - Biaya Pemasaran / } \\
\text { Marketing Cost }\end{array}$ & 450 & 750 & 440 & 640 & 500 \\
\hline - Keuntungan/Profit & 550 & 650 & 1.360 & 360 & 1.000 \\
\hline $\begin{array}{l}\text { - Margin Pemasaran / } \\
\text { Marketing Margin }\end{array}$ & 1.000 & 1.400 & 1.800 & 1.000 & 1.500 \\
\hline $\begin{array}{l}\text { - Harga Jual/Selling Price } \\
\text { - B/C Ratio }\end{array}$ & $\begin{array}{r}4.000 \\
1,22\end{array}$ & $\begin{array}{r}6.000 \\
0,86\end{array}$ & $\begin{array}{r}7.000 \\
3,09\end{array}$ & $\begin{array}{r}6.000 \\
0,56\end{array}$ & $\begin{array}{r}6.000 \\
2,00\end{array}$ \\
\hline $\begin{array}{l}\text { - Harga Beli Pedagang } \\
\text { Pengumpul / } \\
\text { Middleman Price }\end{array}$ & - & 2.700 & 5.100 & 4.200 & 4.000 \\
\hline $\begin{array}{l}\text { - Biaya Pemasaran / } \\
\text { Marketing Cost }\end{array}$ & - & 880 & 100 & 500 & 450 \\
\hline - Keuntungan/Profit & - & 3.020 & 100 & 300 & 50 \\
\hline $\begin{array}{l}\text { - Margin Pemasaran / } \\
\text { Marketing Margin }\end{array}$ & - & 1.900 & 100 & 800 & 500 \\
\hline - Harga Jual/Selling Price & - & 4.600 & 5.200 & 5.000 & 4.500 \\
\hline - B/C Ratio & & 3,43 & 1,00 & 0,60 & 0,11 \\
\hline
\end{tabular}

Sumber: Data Primer Diolah, 2005

Source : Primary Data Proccesed, 2005

mencapai yang diinginkan pembeli. Dari Tabel 5 dapat diketahui bahwa biaya pemasaran terbesar yang ditanggung pedagang besar yang berada di Bima, Sumenep dan Palopo. Biaya terbesar yang ditanggung terbesar untuk pengeluaran penyusutan, transportasi dan bongkar muat.

Hasil perhitungan marjin pemasaran maka marjin pemasaran terbesar diperoleh pedagang besar yang berada di Badung. Hal ini disebabkan karena untuk wilayah Jakarta, rumput laut dijual langsung dari pedagang besar ke pasar eceran, sedangkan untuk dua wilayah lainnya pedagang besar merupakan agen perusahaan atau orang kepercayaan dari perusahaan sehingga rumput laut yang dijual mempunyai harga yang lebih tinggi dibanding di daerah lainnya. 


\section{Analisis Struktur Pasar}

\section{a. Struktur pasar di tingkat pedagang pengumpul}

Hasil pengamatan di lapangan dan wawancara dengan responden yang dilakukan diketahui bahwa jumlah pedagang pengumpul dilokasi sentra produksi jumlahnya terbatas paling banyak 10 orang, bahkan seperti di Badung pedagang pengumpul merupakan lembaga koperasi, sehingga pembudidaya tidak punya banyak pilihan untuk menjual rumput laut. Hambatan yang cukup besar banyak dialami oleh pedagang pengumpul yang baru untuk membeli rumput laut dari pembudidaya. Hal ini disebabkan sudah terjalinnya ikatan yang kuat antara pedagang pengumpul dengan pembudidaya karena banyak diantara pedagang pengumpul tersebut adalah anggota keluarga pembudidaya atau ketua kelompok tani. Selain ikatan kekeluargaan atau kedekatan lain, pedagang pengumpul sering memberikan pinjaman modal kepada pembudidaya sehingga hasil panennya terpaksa harus dijual ke pedagang pengumpul untuk membayar hutang.

Pedagang pengumpul berfungsi sebagai penentu harga rumput laut pembudidaya, informasi harga rumput laut ditentukan berdasarkan kualitas rumput laut yang dijual dan ditentukan sepenuhnya oleh pedagang. Kondisi demikian memperlihatkan bahwa harga rumput laut sangat dipengaruhi oleh mutunya, sehingga struktur pasar rumput laut mengarah pada pasar oligopoli. Menurut Douglas (2001), produk yang dipasarkan dalam pasar oligopoli ini berupa produk yang atributnya distandarisasikan. Uraian di atas dapat disimpulkan bahwa struktur pasar rumput laut di tingkat pedagang pengumpul adalah bersifat oligopoli.

\section{b. Struktur pasar di tingkat pedagang besar}

Hasil pengamatan dan wawancara diketahui bahwa jumlah pedagang besar di setiap lokasi jumlahnya sangat terbatas, paling banyak 3 orang, bahkan di Kabupaten Badung pedagang besar hanya satu. Pedagang besar tersebut biasanya berlokasi di kabupaten. Pedagang besar mempunyai cukup banyak pedagang pengumpul yang ada di lokasi produksi dan mengirim rumput laut kering secara kontinyu. Keterbatasan jumlah pedagang besar menyebabkan tidak banyak pilihan untuk penjualan rumput laut oleh pedagang pengumpul. Ikatan yang kuat juga terjadi antara pedagang pengumpul dengan pedagang besar. Ikatan ini terjadi akibat pemberian pinjaman modal yang cukup besar oleh pedagang besar untuk pembelian rumput laut dari pembudidaya. Harga rumput laut ditentukan sepenuhnya oleh pedagang besar berdasarkan mutu rumput laut yang diterima. Mutu tersebut yaitu meliputi kadar air maksimal 35\%, kadar garam maksimal 1\% serta kotoran maksimal 5\%. Apabila rumput laut yang dikirim tidak sesuai, maka rumput laut tersebut jarang dikembalikan, namun demikian harganya akan disesuaikan.

Hambatan bagi pedagang besar yang masuk pasar sangat sulit, karena sudah ada ikatan yang kuat antara pedagang besar dengan pedagang pengumpul sehingga sulit bagi pedagang besar yang baru untuk mengajak pedagang pengumpul beralih menjual rumput lautnya. Selain itu bagi pedagang besar yang baru harus memiliki modal yang cukup besar untuk memberikan pinjaman kepada pedagang pengumpul yang digunakan untuk pembelian rumput laut ke pembudidaya.

\section{c. Struktur pasar di tingkat Industri/eksportir}

Jumlah industri pengolahan maupun eksportir rumput laut di Indonesia masih terbatas. Dari hasil penelitian, jumlah pabrik pengolahan rumput laut masih sangat terbatas. Hasil wawancara dengan manajer produksi PT. Amarta Sari Lestari yang 
berlokasi di Surabaya, pabrik pengolahan akan mengolah rumput laut menjadi karagenan apabila ada pesanan dan harga rumput laut dunia turun, namun apabila tidak ada, maka pihak pabrik akan menjualnya/ekspor rumput laut kering. Setiap eksportir atau pabrik pengolah mempunyai pedagang besar yang berlokasi di sentra produksi rumput laut, sedangkan lokasi eksportir ataupun pabrik pengolahan terdapat di Ibukota Propinsi, seperti Surabaya, Semarang, Makasar, Denpasar, Jakarta. Rumput laut yang sudah terkumpul banyak tukar mata uang secara tidak terduga.

Penentuan harga pembelian rumput laut oleh eksportir ke pedagang pengumpul ditentukan sepenuhnya oleh pedagang pengumpul. Seperti halnya mutu yang ditentukan pedagang pengumpul, maka syarat mutu yang ditentukan pihak pabrik adalah kadar air minimal 34\%, kadar garam minimal $1 \%$ dan kotoran minimal $5 \%$. Untuk rumput laut yang tidak memenuhi persyaratan akan ditolak atau harganya disesuaikan selama rumput laut tidak terlalu parah. Harga rumput laut yang diterima eksportir tergantung dari

\section{Tabel6. Struktur Pasar Berbagai Tingkat Pemasaran Rumput Laut Kering di Lokasi Penelitian Tahun 2005}

Table 6. Market Structure of Seaweed Marketing Level on Area Research in 2005

Tingkat Pemasar / Level of Seller

\begin{tabular}{ll}
\hline Pedagang Pengumpul /Retailer & Oligopoli / Oligopoly \\
Pedagang Besar/WholeSaler & Oligopoli / Oligopoly \\
Industri Pengolahan atau Eksportir/ & Oligopoli / Oligopoly
\end{tabular}

Struktur Pasar / Market Structure

Industry or Exporter

Source : Primary Data Processed, 2005

akan di ambil oleh pihak perusahaan bagi yang di wilayah yang jauh seperti NTB, Sulawesi Selatan, namun bagi yang lokasinya cukup dekat rumput laut dikirim oleh pedagang besar ke lokasi pabrik.

Hambatan untuk memasuki pasar di tingkat industri pengolahan/eksportir sangat tinggi. Hal ini disebabkan oleh tingginya modal yang harus di miliki, resiko yang relatif tinggi, akses ke pasar luar negeri yang cukup sulit, serta persaingan harga diantara eksportir sendiri. Resiko yang sering dihadapi industri pengolahan/eksportir yaitu mutu rumput laut yang mereka beli tidak sesuai dengan yang diinginkan. Selain itu fluktuasi nilai tukar rupiah yang sangat tinggi, sehingga tidak jarang kerugian diakibatkan oleh perubahan nilai harga rumput laut dunia, dan harga ditentukan dengan dolar. Selain pembelian rumput laut dari dalam negeri, namun banyak diantara pabrik pengolahan tersebut membeli rumput laut dari laur negeri dengan alasan tingginya harga di dalam negeri dan mutu yang lebih baik dari luar negeri.

\section{Analisis Efisiensi Pemasaran}

Secara umum efisiensi merupakan rasio antara output dan input. Efisiensi pemasaran berarti maksimisasi rasio input dan output dari kegiatan pemasaran. Input pemasaran meliputi sumber daya (tenaga kerja, mesin, energi dan lain-lain) yang digunakan dalam fungsi pemasaran. Output 


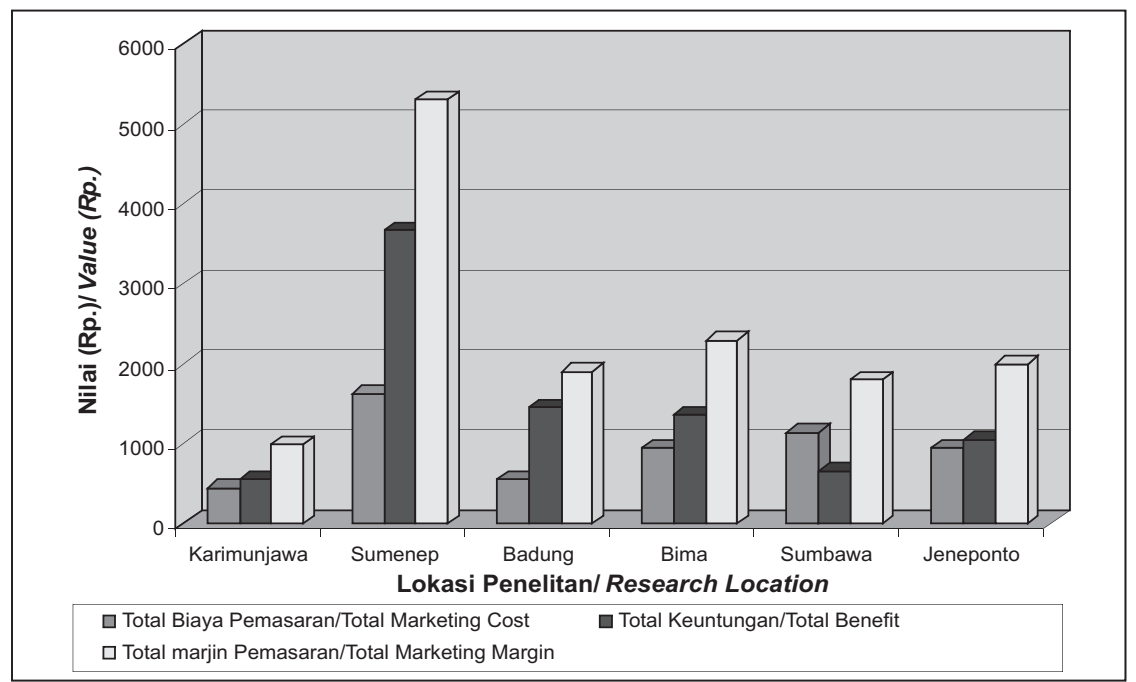

Gambar 2. Total Biaya Pemasaran, Total Keuntungan dan Total Marjin Pemasaran Rumput Laut Di Lokasi Penelitian Tahun 2005

Figure 2. Total Marketing Cost, Total Benefit and Total Marketing Margin of Seaweed at Study Site in 2005

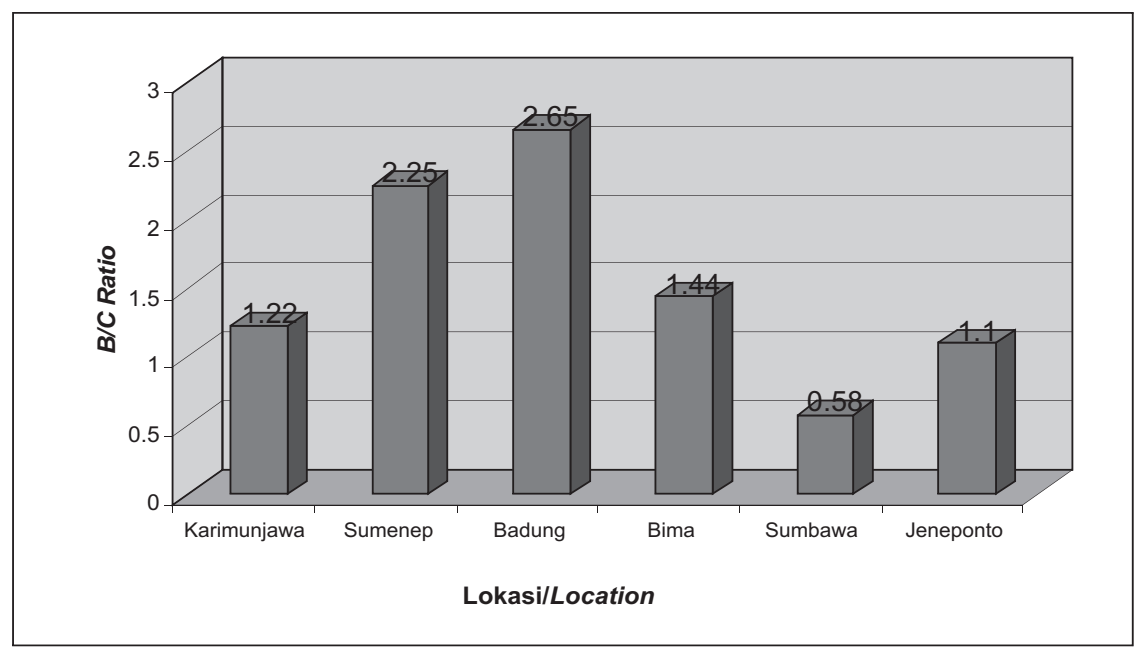

Gambar 3. Total B/C Pemasaran Rumput Laut di Lokasi Potensial Tahun 2005

Figure 3. Total B/C of Seaweed Marketing in Potential Locations of Year 2005 
pemasaran meliputi waktu, bentuk, tempat dan kegunaan lain yang mengarah pada keputusan konsumen. Artinya sumber daya sebagai biaya dan kegunaan sebagai keuntungan dari pemasaran yang akan diperhitungkan dalam efisiensi rasio (Kohl dan Uhl, 1990).

Analisis efisiensi pemasaran dilakukan dengan melihat bagaimana tingkat efisiensi operasional yang diukur dari biaya pemasaran dan marjin pemasaran dimana biaya dan marjin pemasaran yang lebih rendah adalah lebih efisien. Biaya pemasaran rumput laut tertinggi terjadi di Kabupaten Sumenep yaitu mencapai Rp. 1630/kg. Hal ini disebabkan besarnya biaya pemasaran yang dilakukan oleh pedagang pengumpul karena mereka membeli rumput laut dari pembudidaya dalam keadaan basah sehingga biaya susut sangat tinggi., sedangkan biaya pemasaran terendah terjadi di kabupaten Probolinggo. Hal ini disebabkan penjualan rumput laut dari lokasi tersebut tidak melalui banyak pedagang perantara. Rumput laut dibeli dari pembudidaya ke agen yang merupakan kepanjangan tangan dari pihak industri pengolahan.

Total keuntungan pemasaran rumput laut terbesar diterima oleh pedagang di Kabupaten Sumenep yaitu Rp. 3.670/kg. Hal ini disebabkan pembelian rumput laut yang jauh harganya antara pedagang pengumpul dengan pedagang besar. Pedagang pengumpul dengan membeli rumput laut pembudidaya dalam keadaan basah lebih menguntungkan, sedangkan pembelian rumput laut kering oleh pedagang besar juga lebih rendah dibanding daerah lain. Apabila membandingkan marjin pemasaran, maka pemasaran rumput laut yang memiliki margin tertinggi yaitu pedagang di Kabupaten Sumenep Rp. 5.300/kg, sedangkan marjin terendah diperoleh pedagang di Kabupaten Karimunjawa.
Apabila dilihat dari rasio keuntungan dan biaya pemasaran, maka hampir di seluruh lokasi, pemasaran rumput laut mempunyai nilai $B / C$ lebih besar dari satu kecuali untuk lokasi Sumbawa. Hal ini disebabkan harga rumput laut yang diterima pembudidaya dengan yang dibeli pedagang besar sangat jauh perbedaannya. Pedagang pengumpul rumput laut yang berada di beberapa lokasi mengambil lebih banyak keuntungan dibanding lokasi yang mempunyai $\mathrm{B} / \mathrm{C}$ rasio lebih besar. Namun selain wilayah tersebut nilainya lebih dari satu yang artinya setiap biaya yang dikeluarkan sebesar satu unit akan menghasilkan keuntungan lebih dari satu unit. Rasio B/C terbesar di peroleh pedagang berturut-turut di Badung dan Sumenep.

Dari uraian di atas dapat dilihat bahwa pemasaran rumput laut yang paling efisien adalah di lokasi Badung dan Sumenep. Hal ini disebabkan di Badung efisien karena biaya pemasaran yang dikeluarkan paling rendah di tingkat pedagang pengumpul dan jalur pemasaran yang pendek. Di Sumenep, B/C ratio di tingkat pedagang pengumpul lebih besar dibanding wilayah lain, karena selisih harga jual dan harga beli terlalu jauh.

\section{KESIMPULAN}

Dari hasil analisis pemasaran yang dilakukan dapat disimpulkan bahwa:

1. Lembaga pemasaran yang terlibat dalam pemasaran rumput laut terdiri dari pedagang pengumpul yang ada di lokasi produksi, pedagang besar yang berlokasi di ibukota kecamatan atau kabupaten serta industri ataupun eksportir yang ada di ibukota propinsi

2. Struktur pasar rumput laut di seluruh tingkat pedagang pengumpul, pedagang besar dan industri serta eksportir bersifat 
oligopoli artinya dengan jumlah pedagang yang sedikit maka akan muncul pedagang yang paling dominan dalam struktur pasar ini dan pedagang tersebut dapat menjadi pedagang yang memiliki pangsa pasar terbesar sehingga pedagang ini dapat bertindak sebagai penentu harga (priceleader) dan memiliki jalur distribusi yang kuat.

3. Pemasaran rumput laut yang paling efisien yaitu di lokasi Karimun Jawa, kemudian diikuti oleh wilayah lain seperti Sumbawa, Badung, Jeneponto, Bima dan Sumenep.

\section{DAFTAR PUSTAKA}

Dahuri, R. 2004. Paradigma Baru Pembangunan Indonesia Berbasis kelautan. Makalah Orasi IImiah. Institut Pertanian Bogor. 233 hal

Dinas Perikanan dan Kelautan. 2004. Laporan Tahunan. Kabupaten Jeneponto.

Dinas Perikanan dan Kelautan. 2004. Laporan Tahunan. Propinsi Nusa Tenggara Barat.
Douglas, M. A. 2001. Managerial Economics : Analysis and Strategy. Penerbit Prentice Hall International Edition. Fourth Edition. USA

Kotler. 1999. Marketing Management an Asian Perspective. Penerbit Prentice Hall. Singapore.

Kohls, R.L dan J.N Uhl. 1990. Marketing of Agricultural Products. Seventh Edition. Mac Millan Publishing Company, New York.

Kuncoro, M. 2002. Analisis Struktur - Prilaku Kinerja Argo Industri Indonesia: Suatu Catatan Empiris Kelola Gadjah Mada, University Business Review, no.11/VI.

Nikijuluw, V. P. H. 2005. Politik Ekonomi Perikanan: Bagaimana dan Kemana Bisnis Perikanan? PT. Fery Agung Corporation (FERACO). Jakarta. 314 hal. 